\title{
PETER BERGER AND HIS SOCIOCULTURAL-PHENOMENOLOGICAL RESEARCH
}

\section{E. A. Timoshchuk}

Russian Academy of National Economy and Public Administration, Vladimir, Russia e-mail: timoshchuk-ea@ranepa.ru

\begin{abstract}
The phenomenological paradigm in sociocultural research is the relay race of Husserl - Schütz Luckmann and Berger. Despite the first difference between sociology and phenomenology, the emphasis on design, biography, historical context, subjectivity and experience only complement quantitative research with the necessary quality of humanism. Today, when technocratic line is becoming a leading trend, when people talk about neuro-turnaround in science and social practices, phenomenology must be given credit for its courage in sociocultural subjectivity and the actualization of the philosophy of consciousness. Scientometric absorption of the subject is a dangerous way of deflation of philosophy, its reduction to the functional support of the brain-machine interface.

The sociocultural phenomenologist Peter Berger (1929-2017) died a year after the demise of his and co-author Thomas Luckmann. Last year there was also jubilee of the founder of phenomenology, Edmund Husserl, who turned 160 years old. The scientometric absorption of the subject is a dangerous way of deflation of philosophy, its reduction to the functional support of the brain-machine interface. The study of the heritage of P. Berger in this regard allows us to proceed to the efficient processing of Husserl's ideas in the field of describing the valuesemantic world of society and culture.

The author proceeds with the study of the model of the socio-cultural and anthropological world, constructed by Peter Ludwig Berger. The subject of the research is the theoretical framework of the phenomenology of society and culture. The main provisions of Berger's sociocultural phenomenology are: 1) secularization has a heterogeneous porous structure, 2) under capitalism, transcendence is possible as a personal spiritual practice; 3) pluralism of social orders and globalization are the basis for restrained forecasts regarding the society of the future; 4) the clash of bureaucracy and the private is removed by the daily routine of meaning generation. Pursuing issues of the privatization of religion, the theory of modernization, the sociology of knowledge, Berger's sociocultural phenomenology turns everyday life into a fascinating scientific quest. He easily moves from concrete to abstract and vice versa, but does not throw the reader into the abyss of lifeless ideas. At the same time, the sociologist makes it clear that he is ready to change his mind, he does not close us in a rigid configuration of ideas, yet places the reader in the bootstrap reality.

Berger remained in phenomenological position, describing social structures in terms of construction, typification, collective understanding, legitimization of social memory, horizons of reality, habitualization of meanings, reification of meanings, objectification of the lifeworld of utopias. Main conclusions. The sociocultural phenomenology of P. Berger allows you to value-correlate the sacrifices made by capitalism and communism to build a social order. His phenomenology is the method of contextual correlation of different social worlds - science and religion, secular and transcendental, personal and collective. Bergerian sociocultural subjectivism opposes the reduction of philosophy to the information support of a technogenic society and the maintenance of science.

Key words: phenomenology of culture, sociocultural phenomenology, phenomenology of religion, desecularization, globalization, modernization, Berger, Luckmann, Husserl.

Cite as: Timoshchuk, E. A. (2020) [Peter Berger and his sociocultural-phenomenological research]. Intellekt. Innovatsii. Investitsii [Intellect. Innovations. Investments]. Vol. 5, pp. 146-151. DOI: 10.25198/2077-7175-20205-146.
\end{abstract}

\section{ПИТЕР БЕРГЕР И ЕГО СОЦИОКУЛЬТУРНО-ФЕНОМЕНОЛОГИЧЕСКИЕ ИССЛЕДОВАНИЯ}

\section{Е. А. Тимощук}

Российская академия народного хозяйства и государственной службы, Владимир, Россия e-mail: timoshchuk-ea@ranepa.ru

Аннотация. Феноменологическая парадигма в соичиокультурных исследованиях - это эстафета Э. Гуссерль - А. Шюи - Т. Лукман и П. Бергер. Несмотря на различие сочиологии и феноменологии, акиент 
на конструировании, биографистике, историческом контексте, субъективности и пережсвании только дополняет количественные исследования необходимым качеством человечности. Сегодня, когда технократизм становится ведущим направлением, когда говорят о нейроповороте в науке и сочиальных практиках, нужно отдать должное феноменологии за её мужество социокультурного субъективизма и актуализацию философии сознания. Наукометрическое поглощение субъекта - это опасньй путь дефляции философии, её редукции до функционального обеспечения интерфейса «мозг-машина». Изучение наследия Питера Бергера в этой связи позволяет уйти от обезличенности и дать сочуиально-исторический контекст жизненного мира субъекта в его ситуации «работа», «игра», «мечта», «фантазия».

Объектом изучения является модель соџиокультурного и антропологического мира, сконструированная Питером Людвигом Бергером. Предметом исследования выступает теоретический каркас феноменологии общества и культуры. Основные положения социокультурной феноменологии Бергера: 1) секуляризация имеет неоднородную пористую структуру, 2) в условиях капитализма трансиендендирование возможно как личная духовная практика; 3) плюрализм сочиальных порядков и глобализация служат основанием для сдержанных прогнозов в отношении общества будущего; 4) столкновение бюрократии и приватного снимается повседневностью смыслогенерации. Занимаясь вопросами приватизации религии, теорией модернизации, социологией знания, сочиокультурная феноменология Бергера превращяает обыденность в увлекательный научный квест. Он легко переходит от конкретного к абстрактному и наоборот, но не бросает читателя в пучину безжизненных пресных идей. Одновременно с этим, социолог даёт понять, что готов изменить своё мнение, он не закрывает нас в жёсткой конфигурации идей, а оставляет читателя в реальности бутстрапа.

Бергер оставался на феноменологических позициях, описывая социальные структуры в терминах конструирования, типизации, коллективного понимания, легитимизации социальной памяти, горизонтов реальности, хабитуализации смыслов, реификации значений, опредмечивания жизненного мира утопий. Основные выводы. Социокультурная феноменология П. Бергера позволяет ценностно соотнести жертвы, на которые идут капитализм и коммунизм для выстраивания социального порядка. Его феноменология выступает методом контекстного соотнесения разных сочииальных миров - науки и религии, мирского и трансцендентного, личного и коллективного. Бергерианский социокультурный субъективизм противостоит низведению философии до информационного обеспечения техногенного общества и обслуживания науки.

Ключевые слова: феноменология культуры, сочиокультурная феноменология, феноменология религии, десекуляризаџия, глобализащия, модернизаџия, Бергер, Лукманн, Гуссерль.

Для цитирования: Timoshchuk, E. A. (2020) [Peter Berger and his sociocultural-phenomenological research]. Intellekt. Innovatsii. Investitsii [Intellect. Innovations. Investments]. Vol. 5, pp. 146-151. DOI: 10.25198/20777175-2020-5-146.

\section{Introduction}

Peter Berger made significant contributions to the sociology of knowledge. His book The Social Construction of Reality, co-authored with Thomas Luckman, has become one of the ten most influential sociological works of the 20th century and has been translated into more than 20 languages.

Fleeing Nazi persecution following the Anschluss of Austria in 1938, his parents took refuge in Palestine and Berger received the impetus of pluralism from childhood, living among Muslims, Jews, and Catholics. Studying sociology in the United States in the postwar years, Berger chose topics about Protestant Puerto Ricans in East Harlem and the Bahá'í movement in Iran.

Humanism, plurality, and attention to detail are the principles of his scientific position. His motto: «modernity is characterized not by the absence of God, but by the presence of many».

\section{Research methodology}

The theoretical framework of the phenomenology of Peter Berger has many anchor points. Here we have the processes of secularization / resacralization, privatization of religiosity in a market society, pluralism of social orders and globalization, the generation of meaning in everyday life, the theory of modernization and the role of bureaucracy in sociology of knowledge [3, 4].

Dealing with a wide variety of issues of social philosophy, Berger easily incorporates and at the same time criticizes ideas of K. Marx, M. Weber, E. Durkheim, J. Mead, A. Schutz, as if illustrating social constructivism by his very course of thinking. His intellectual conscientiousness does not allow him to close the reader in a theoretical tower of silence. On the contrary, he pushes us to study the topic on our own [15]. The intellectual project of cultural sociology conveys a simple, and, as we see, an obvious and undeniable message that the fabric of sociocultural reality is woven by many participants in society and is gradually being built into the institutional structure of society. This process is described phenomenologically as intentional and intersubjective maintenance of an array of social knowledge, which is most often grounded only in social interactions and a request to protect the stability of 
the lifeworld of different communities. The symbolic worlds of social groups intersect, compete, intervene, legitimize new orders, generate historical descriptions of their significance.

Berger's distinctive feature is the constructivist application of phenomenology to social cognition, which gave a hybrid-modular understanding of society or the realization that the society we have is produced by our objectified ideas [7].

\section{Bergerian paradigm}

When Berger was director of the Institute for the Study of Economic Culture, he studied the relationship between global socio-economic change and a wide range of issues - culture, beliefs, values, lifestyle. He always recognized the usefulness of transnational research. If a researcher interested in his society, it can always be understood much better by comparison with others.

Berger took a keen interest in social development and public policy issues. In particular, he studied the socio-economic implications of tuning the interaction between capitalism and democracy [3].

It is usually considered that capitalism and democracy are concomitant processes: the first is a condition for democracy, and democracy necessarily leads to market relations. While this is true in Western societies, where capitalism cannot be found apart from the market economy, Berger points out that the market and democracy are not always complementary: there may be capitalist societies that lack democratic institutions. However, democratic society with a socialist economy is not known, therefore there is no transitivity in the relations between the market and democracy. On the other hand, there is no theoretical limitation that there can be no democracy if there is no market economy.

Despite the asymmetry «there is no democracy without a market economy, but there is a market economy without democracy», the market somehow creates the preconditions for democracy through the same middle class, which seems to be inclined towards democracy. The middle class uses existing hedge funds, stock exchanges, banks, associations, human rights movements as a tool to defend its interests and resist the dictatorial regime. These are institutions that help to resist the dictatorship. It needs autonomy and does not like overregulation.

Thus, capitalism launches some processes to constrain the dictatorship. However, this does not mean that the more market there are ties with China and the West, the more China becomes democratized.

Berger has always believed that intercultural research is important for understanding society. Due to global capital flow and economic mondialism, cultural trends in the United States have also been modified. Berger has always described globalization as a much more complex set of phenomena than the popular im- age of American imperialism. Indeed, global culture is heavily influenced by the values of Western consumer society. However, many non-American cultures are contributing to the globalization process. This applies to Buddhism and Islam, Confucianism and Hinduism [5].

The phenomenon of cultural globalization has accelerated the creation of a successful and prosperous non-white middle class. Racial segregation cannot coexist with an integrated world economy - this is objectively a blessing from world economic culture. On the other hand, globalization leads to grave consequences, both socially and culturally: entire industries, jobs, professional cultures disappear.

Increasing job and capital mobility exacerbate another trend: a weakening of civil society. People are less likely to devote time to local communities - voluntary associations, church groups that have traditionally shaped the fabric of American society. Social capital has become more heterogeneous, and there is a tendency to move from lifetime membership in an organization to event participation. The number of active volunteers has decreased as women began to pay more attention to work. Their way of volunteering has changed.

The danger of romanticizing the idea of civil society should also be borne in mind. Not all intermediary structures are good. Certain civil mediation structures can be dangerous (nationalist groups, ex-convicts communities, street racers, football fans).

\section{Life-world}

The intentionality of sociocultural being is a significant topic for Peter Berger. He draws attention to how the reification of our life-world takes place. Our news feed has become truly intentional: «the politician thinks over», «the deputies are planning», «the mayor considers», «the parliamentarians appreciated the idea», «the authorities presumed the introduction of responsibility». Phenomenology, dealing with the problem of reconciling the life-worlds, describes the procedures for negotiating the world of meanings, which is generated, experienced, supported and interpreted by people in their everyday life. The conjugation of different systems of relevance means coding the sphere of action into the symbolic world and vice versa, decoding information from the symbolic level. The world of meanings in the situation of agreement and feedback retains plasticity, mobility, and dynamics. Life in sociocultural phenomenology appears as an open field of communication, socialization, and resocialization.

There are several thought experiments doing heart (head) transplants, which show that this does not affect the range of values. Artistic and ethical narratives (Fedor Dostoevsky «Anecdote about the rearrangement of heads», A. Belyaev «Head of Professor Dowell», T. Mann «The Transposed Heads», M. Bulgakov 
«Heart of a Dog») consider the anthropological and ethical difficulties of transferring central organ, an operation that is still outside the successful implementation of medicine. The Kafkaesque narrative about the metamorphosis of a person turned into an insect («The Metamorphosis») is now possible not only as a literary experiment but also as a virtual augmented reality.

The phenomenological thought experiment on the transponder of the life-world is that if we change the places of biographical situations, we simultaneously affect the systems of relevance. The relationship of the biographical type, lifeworld, language is interconnected and structured. Out of the totality of the experienced experience, why does the subject make only certain situations and happenings relevant for himself, composing based on samples of habitual actions, communication styles, linguistic and cultural practices [10]?

Without pretending to be an empirical substitution, phenomenology offers a framework for interpreting the boundaries of the subject's interest as a social actor. Biographical non-transitivity leads to the fact that meanings must be constantly and invariably attributed. The determinants of intentional reflexivity are the object, course of activity, environment, rules of social role play [16].

The structure of the lifeworld is created from the negotiation of «I» and «You», synchronously and asynchronously putting themselves in the place of the Other, with the help of imagination projecting an interpersonal given. Their shared experience becomes «We». «I» transfers to "You» its schemes, motives, expectations to experience the corresponding states. The intersubjective world is the phenomenological context of social life. Thus, a large community of «I» and «You», called a nation, is the unity of the experience of historical fate, similar values and common motives. Experiencing the relationships of the closest environment creates an objectified social model, within which a personal story about one's personal life gives a great experience of social interpretation

\section{Sociocultural phenomenology of religion}

The most striking feature of Peter Berger became the assertion of religion as a special social cover of mankind, protecting against everything unknown, dangerous and unstable. Such a proposition in secular society sounded bold and unexpected. For several decades, the sociologist Peter Berger has been one of the most interesting writers on religion and modern society. In The Sacred Veil (1967), Berger reveals religion as a social construct that society erects over its everyday life to give meaning and protection from the unknown [12].

In «A Rumor of Angels» (1969), he seeks to recognize the signals of the transcendent in a secular society. Contrary to the hegemony of secularization, he shows signs of a divine presence in hierarchy and play, dreams and fears, humor and curses [2].
Monography «Redeeming Laughter: The Comic Dimension of Human Experience» (1987) continues to search for signals of the transcendent in modern culture. This is the theology of laughter, which has a special place among the diversity of human emotions. Berger reflects on the nature of the comic and its connection with spiritual experience. Humor, irony, satire, stupidity give us the experience of transcending the bodily. It is a kind of atonement for man's sinful existence.

Laughter transcends because at this moment the mode of serious perception of the world is suspended and a magical shell of invulnerability is created. A similar meaning to fun can be seen in the psychological component of escape from everyday life. Laughter, as it were, gives us the short-term hope of a redeemed future without pain and suffering. Humor is a momentary island of safety and well-being, and this is its bizarre and illusory similarity to religion [9].

The nature of religious beliefs in the modern world is considered by him in other monographs. In «A far glory: the quest for faith in an age of credulity» (1992), Berger confronts the transcendental message of Christianity and the new informational middle class in the United States that is creating non-state religiosity. It is an example of American neoconservative religious thought, where Berger encourages Christians to adhere to their fundamental values and discovers in the creed individualism, belief in the utmost goodness of the universe and the reality of God who embraces «fullness» and «emptiness» [1].

Berger is concerned about the fate of civil society in connection with the unbridled individualism in the United States, the spread of autonomization of the self. Sociologist Robert Bella or philosopher Hilary Putnam condemned excessive individualism as a potential threat to social cooperation. However, Berger believes that this is not empirically supported. Anomy and growing loneliness are hypertrophied constructs supported by some in the academic community. Many «individualists» are quite successful in social activities of one kind or another, participate in different communities, donate time and money. Associativity, communication, interaction are the basis and attractive side of the dynamic American life. Besides, Americans are considered more conformist and more prestigious than, for example, the French or Italians, which contradicts the fact that they are over-individualists [14].

The atomized individual loses the ability to take on obligations and this is good for politicians who fear even a hint of communism and communitarianism, knowing about the millions of citizens of the USSR and China who died during the «purges» and collectivization. Socialist theorists have built models on the altar of which pyramids of sacrifice have been brought, but is capitalism sinless? Its prosperity and success is on the other pyramids of victims, - colonial ones [13, c. 4-19]. 
Any theoretical constructions, on the altar of which sacrifices are made, resemble Plato's «State», the first ideological basis for rejecting the authenticity of the experience of the Other and providing a pragmatic basis for radical social transformation. Berger brings us back to the phenomenological authenticity of the Other's experience.

\section{Secularization}

Berger devoted a lot of time to the topic of secularization and largely due to him, the views of scientists have undergone some changes in comparison with the views of the 1960s. In his works, he argued that modernization does not mean automatically growing secularization [8]. Earlier it was believed that the more modernized a society becomes, the more irreligious it is, but this was a misconception, as Berger convinces us [6]. His main thesis was that religiosity and modernity go hand in hand. More modernization does not mean more secularization. First, most of the world today is not secular. Southeast Asia and Latin America are generally very religious. Secondly, even in the most secular USA and Western Europe, the number of non-believers is an absolute minority, however, since they represent the cultural elite, they set the general tone of agnosticism and secular humanism through science and education.

Third, it was the secular era that became the heyday of post-liberal, neo-orthodox religious groups that advocated the restoration of their theological identity, a re-immersion in tradition, for the purification of the language and scripture narrative from compromises with a changing lifestyle. It was in the era of fencing off governments from religion that mass movements in the form of Liberation Theology, Islamic Revolution and Reform Catholicism were born.

Consistent state laicism made possible the rapid spread of new religious movements in the 20th century, which intensified competition between new and old religions for the flock. The oldest world religion, Buddhism, received a new life through psychology, esotericism, New Age movement. Missionary work, conversion, God-seeking, and the phenomenon of «radical converts» have become prominent factors in social life. Stories about sectarians, Witnesses, Hare Krishnas, evangelists, Mormons, and Scientologists regularly hit the media. Pentecostals and Charismatics are gathering stadiums for new Christians. The political activity of Jews and Orthodox, Catholics and Protestants is quite noticeable [11].
Resacralization is the answer to secularization. The problem with liberal Protestantism is not a loss of orthodoxy, but a loss of religious essence. Therefore, it was followed by a post-liberal movement to restore its theological identity and re-immerse itself in tradition, in the language and narration of the scriptures. At a certain stage, believers are no longer satisfied with the psychologization and politicization of religion, when the church turns into a therapeutic and powerful agent. The Church occupies new niches, becoming a healer and agent of change, a political institution. Psychologization, politicization, globalization of religion is a response to a person's need to maintain self-identity in a rapidly changing world. However, immersion in psychology and politics is futile for religious organizations, because there is always an abundance of institutions in society that do it in a more professional and modern way.

The challenge of non-classics - to live with uncertainty, like a quark, turned out to be unacceptable for a person. We want a classic, stable, predictable world, and this is the conservative position of religion. Even the phenomenon of mass cultural-religious identity without churchliness retains an axiological line of certainty, though not a fanatic, but not a relativist either. Everyday religion is another way to express your certainty.

\section{Conclusion}

Thus, Peter Berger is influential as a consistent apologist of culture and humanism, who equally criticized the sacrifices that capitalism and communism make to build a social order. As a sociologist and theologian, he recognized the signs of the divine in everyday moments of our lives and put forward a highly scientific proposition of epistemological modesty in the midst of the «God is dead» hype. The phenomenologist made a thesis of the preservation of the significance of religion in modern society. Berger died on June 27, 2017, at his home in Brooklyn, Massachusetts at the age of 88 . He was distinguished by an honest scientific approach, which meant that, as a sociologist, he tried to take into account all social trends, receiving signals from the elite and the lower classes, from developed and developing countries, from priests and atheists, oligarchs and homeless people. For him, social information is what he is ready to analyze for a diverse array of public discourses, including rumors. Working with radical anti-militarists and human rights activists, he remained a neo-conservative and critic of revolution.

\section{References}

1. Berger, P. (1992) A far glory: the quest for faith in an age of credulity. New York, Maxwell Macmillan International, $218 \mathrm{p}$.

2. Berger, P. (2011) A Rumor of Angels: Modern Society and the Rediscovery of the Supernatural. Open Road Media, 129 p.

3. Berger, P., Berger, B., Kellner, H. (1973) The Homeless Mind: Modernization and Consciousness. NY: Random House, 258 p. 
4. Berger, P. (1977) Facing Up to Modernity: Excursions in Society, Politics, and Religion. New York: Basic Books, 233 p.

5. Berger, P., Huntington, S. (2003) Many Globalizations: Cultural Diversity in the Contemporary World. NY: Oxford University Press, 390 p.

6. Berger, P. (1981) The Other Side of God: A Polarity in World Religions. Anchor Press/Doubleday, 304 p.

7. Berger, P. Luckmann, T. (1966) The Social Construction of Reality. New York: Anchor Books, 240 p.

8. Berger, P. (2014) Many Altars of Modernity. Towards a Paradigm for Religion in a Pluralist Age. Berlin: de Gruyter, $161 \mathrm{p}$.

9. Berger, P. (2014) Redeeming Laughter: The Comic Dimension of Human Experience. Berlin: De Gruyter, 226 p.

10. Berger, P. (1998) The Limits Of Social Cohesion Conflict and Mediation In Pluralist Societies. New York: Perseus, 420 p.

11. Berger, P. (1976). The Precarious Vision: A Sociologist Looks at Social Fictions and Christian Faith. NY: Doubleday \& company, $238 \mathrm{p}$.

12. Berger, P. (1990) The Sacred Canopy: Elements of a Sociological Theory of Religion. Anchor, 240 p.

13. Berger, P. (1976) Pyramids of Sacrifice: Political Ethics and Social Change. Anchor, 240 p.

14. Berger, P. Epistemological Modesty: An Interview with Peter Berger. Available at: https://www.religiononline.org/article/epistemological-modesty-an-interview-with-peter-berger/ (accessed 12.04.2020).

15. Martin, D. (2012) The Essence of an Accidental Sociologist: An Appreciation of Peter Berger // Society March, Volume 49, Issue 2, pp. 168-174. https://doi.org/10.1007/s12115-011-9522-8

16. Nenon, T. (1999) The Phenomenological Foundation of the Social Sciences. Schutzian Social Science / Embree L. Dordrecht: Kluwer Academic Publishers, pp. 173-186.

\section{Information about the author:}

Elena Andreevna Timoshchuk, PhD in Philosophy, Associate Professor, Department of Social and Humanitarian Disciplines, RANEPA, Vladimir, Russia

ORCID ID: 0000-0002-4525-8174

e-mail: e@timos.elcom.ru

The paper was submitted: 22.04.2020.

Accepted for publication: 19.08.2020.

The author has read and approved the final manuscript.

\section{Информация об авторе:}

Елена Андреевна Тимощук, кандидат философских наук, доцент кафедры социально-гуманитарных дисциплин Владимирского филиала РАНХиГС, Владимир, Россия

ORCID ID: 0000-0002-4525-8174

e-mail: e@timos.elcom.ru

Статья поступила в редакцию: 22.04.2020; принята в печать 19.08.2020.

Автор прочитал и одобрил окончательный вариант рукописи. 